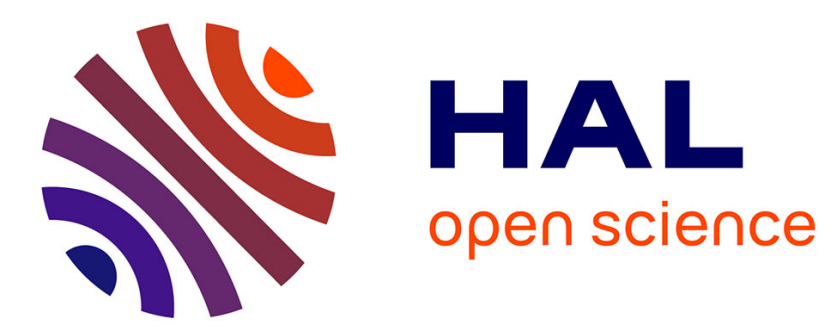

\title{
Borinic acid catalysed peptide synthesis
}

Tharwat Mohy El Dine, Jacques Rouden, Jérôme Blanchet

\section{To cite this version:}

Tharwat Mohy El Dine, Jacques Rouden, Jérôme Blanchet. Borinic acid catalysed peptide synthesis. Chemical Communications, 2015, 51 (89), pp.16084-16087. 10.1039/c5cc06177f . hal-01793138

\section{HAL Id: hal-01793138 \\ https://hal-normandie-univ.archives-ouvertes.fr/hal-01793138}

Submitted on 28 Jun 2018

HAL is a multi-disciplinary open access archive for the deposit and dissemination of scientific research documents, whether they are published or not. The documents may come from teaching and research institutions in France or abroad, or from public or private research centers.
L'archive ouverte pluridisciplinaire $\mathbf{H A L}$, est destinée au dépôt et à la diffusion de documents scientifiques de niveau recherche, publiés ou non, émanant des établissements d'enseignement et de recherche français ou étrangers, des laboratoires publics ou privés. 


\title{
Borinic acid Catalysed Peptide Synthesis
}

\author{
Tharwat Mohy El Dine, Jacques Rouden, and Jérôme Blanchet*
}

The catalytic synthesis of peptides is a major challenge of modern organic chemistry hindered by the well established use of stoichiometric coupling reagents. Herein, we describe the first borinic acid able to catalyse this reaction under mild conditions with an improved activity compared to our recently developed thiophene-based boronic acid. This catalyst is particularly efficient for peptide bond synthesis affording dipeptides in good yields without detectable racemization.

The synthesis of peptides via the assembly of chiral $N$-protected $\alpha$ amino acids and $\alpha$-aminoesters is a well-known methodology. ${ }^{1}$ This essential transformation could be easily realized with high level of predictability owing to the progress made with the use of stoichiometric peptide coupling reagents (Figure 1$)^{2}$
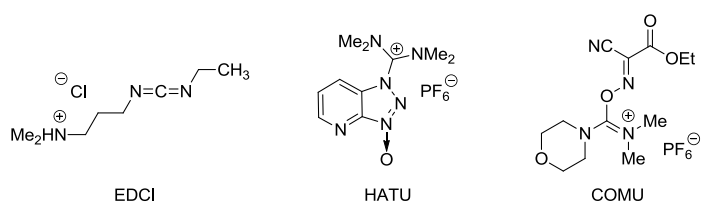

Figure 1. Representative coupling reagents in amide and peptide synthesis.

Despite those great accomplishments, a catalyst that would be able to achieve similar efficiency is still to be discovered. Albeit the catalytic synthesis of amides from simple carboxylic acids and amines has been reviewed several times ${ }^{3}$, almost no information concerning the assembly of two $\alpha$-amino acids derivatives is available. Compared to simple carboxylic acids and amines, protected $\alpha$-amino acids are challenging substrates, due to their weaker nucleophilic character of the amine function and increased steric hindrance caused by the side chain.

Inspired by Yamamoto's pioneering work ${ }^{4}$, Hall ${ }^{5}$ (3a-b, Figure 2), $\operatorname{Tam}^{6}$ (4, Figure 2) and our laboratory (5, Figure 2$)^{7}$ have recently reported boronic acids able to promote room temperature coupling of non-activated carboxylic acids and amines. Regarding peptide synthesis, 25 mol\% of boronic acid $\mathbf{5}$ was found to promote the formation of Boc-Phe-Val-OMe in $50 \%$ yield with no detectable racemization, thus achieving the first synthesis of a dipeptide using a simple chemical catalyst.

Previously, the coupling of protected $\alpha$-amino acids has been explored by Whiting ${ }^{8}$ using stoichiometric quantities of a combination of aryl boronic acids 1-2 (Figure 2). However, low to moderate yields of the corresponding dipeptides were obtained. Interestingly, a cooperative effect of combined catalyst systems was suggested to be beneficial when $50 \mathrm{~mol} \%$ of $1 \mathbf{a}$ and $50 \mathrm{~mol} \%$ of $\mathbf{1 b}$ were used together for the coupling of hindered valine derivatives. ${ }^{9}$

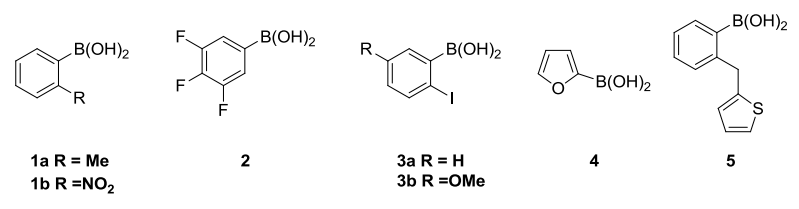

Figure 2. Aryl boronic acids investigated by Whiting, Hall, Tam and Blanchet.
Although peptides are of great value to pharmaceutical industry, their catalysed synthesis is still unknown. Therefore, the next challenge lies in identifying an efficient catalyst that would directly couple $\mathrm{N}$-protected and $\boldsymbol{C}$-protected $\alpha$-amino acids to provide the desired dipeptides in reasonable yields without racemization.

Since boronic acid $\mathbf{5}$ has shown moderate activity in peptide coupling, we decided to shift to a potentially more reactive boron derivative. We hypothesized that the use of borinic acids, which possess an amplified Lewis acidity at the boron centre ${ }^{10}$, can provide an improved catalytic system. Additionally, they offer an improved structural flexibility for further tuning of the electronic and steric properties with two aromatic moieties being attached to the same boron atom. In this context, we report the use of borinic acids for catalysed peptide synthesis.

We started our investigations by synthesizing a library of biaryl borinic acids according to known procedures (See Supporting Information). The reactivity of these borinic acids was compared to a set of commercially available boronic acids in the model reaction carried out between phenylacetic acid $\mathbf{6}$ and benzylamine $\mathbf{7}$ (Table 1). Interestingly, higher yields were systematically obtained with the borinic acids. With electron donating group substituted borinic acids $9 \mathrm{c}(4-\mathrm{t}-\mathrm{Bu}), 9 \mathrm{~d}(4-\mathrm{MeO})$ and $\mathbf{9 e}$ (3-MeO) $39-59 \%$ isolated yields were obtained when the corresponding boronic acids were found to be essentially unreactive (Table 1, Entries 3 and 4).

Table 1. Borinic acids vs boronic acids in the coupling of acid 6 and amine 7. ${ }^{\mathrm{a}}$

$\mathrm{ArB}(\mathrm{OH})_{2}$ or
Entry

${ }^{a}$ Reaction conditions: Phenylacetic acid 6 (0.55 mmol), benzylamine 7 (0.50 $\mathrm{mmol}$ ) and molecular sieves ( $1 \mathrm{~g}$ of $5 \AA$ activated powder) were stirred in dry $\mathrm{CH}_{2} \mathrm{Cl}_{2}(7 \mathrm{~mL})$ with borinic acids $9 a-e$ or boronic acid $(10 \mathrm{~mol} \%)$ under inert atmosphere for $48 \mathrm{~h}$ at room temperature.

Encouraged by these results, the screening of various aryl borinic acids was undertaken. Based on Hall's previous work, ${ }^{5}$ we focused our attention on halogen substituted borinic acids.

The presence of a fluorine atom at the ortho position in 9 f decreased the yield to $63 \%$ compared to the $81 \%$ yield obtained with the fluorine at the para position $9 g$ (Table 2, Entries 1 and 2). A different picture was observed with the introduction of a chlorine 
atom. Indeed, the 2-chloro substituted $9 \mathrm{~h}$ was found to be very effective delivering a quantitative yield of the amide 8 (Table 2, Entry 3) and suggesting that increased electronegativity at the ortho position in $\mathbf{9 f}$ lowered the reactivity of the catalyst. The importance of the ortho-chloro substituent was shown by the lower yields (76\% and $46 \%$ respectively) obtained with the meta $9 \mathbf{i}$ and para $9 \mathbf{j}$ substituents (Table 2, Entries 4 and 5). 2-Bromo substituted 9k led to a similar reactivity as $\mathbf{9 h}$ (Table 2, Entry 6 ), however, with a much less pronounced availability. ${ }^{11}$ These results suggest the need for a specific electronic requirement in the ortho position for an optimal catalytic performance.

Hall and co-workers have reported a dramatic improvement of the performance of boronic acid 3a (Figure 2) when an electron donating group was introduced para to the halogen atom. In their study, the 5-methoxy substituted $\mathbf{3 b}$ was identified to provide faster reactions thus supporting the role of the ortho iodo substituent as a hydrogen-bond acceptor in the proposed transition state. $^{5 a}$ Based on these results, we prepared the 5-methoxy substituted borinic acid 9 .

Table 2. Aryl borinic acid screening. ${ }^{\text {a }}$

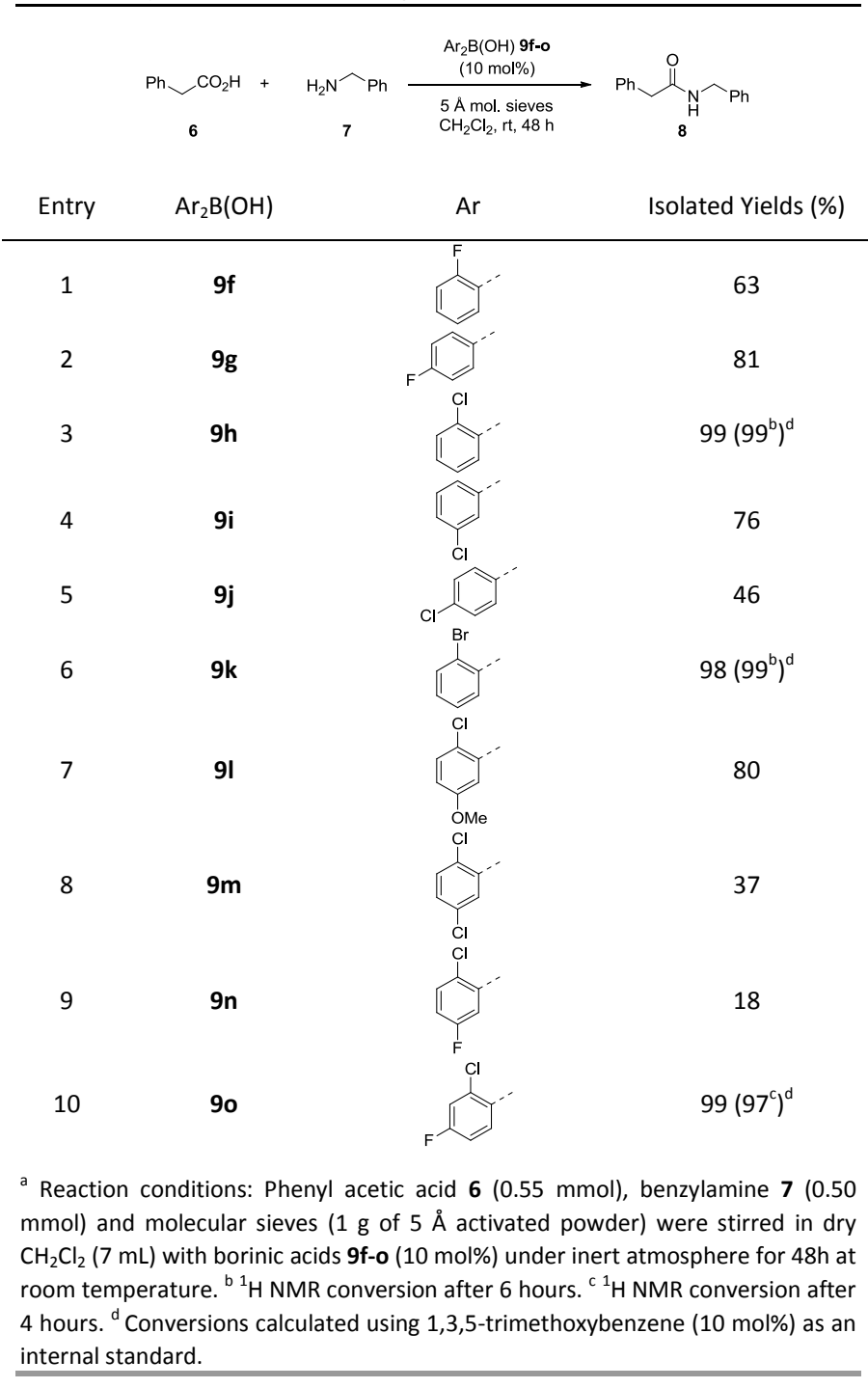

However, in our hands, catalyst 9l was less effective affording amide 8 with $80 \%$ yield (Table 2, Entry 7). Substituting the methoxy group with a chlorine or fluorine atom significantly decreased the catalyst performance ( $9 \mathrm{~m}$ and $9 \mathrm{n}, 37 \%$ and $18 \%$ yields respectively, Table 2, Entries 8 and 9). Interestingly, switching the fluorine position para to the boron atom in 90 enhanced the catalytic activity with $97 \%$ conversion being attained within 4 hours $(99 \%$ yield, Table 2, Entry 10) compared to $99 \%$ conversion attained within $6 \mathrm{~h}$ with catalyst $9 \mathrm{~h}$ (99\% yield, Table 2, Entry 3). These results illustrate the importance of fine-tuning the electronic properties of the catalyst in terms of electron-density of the orthohalogen and boron Lewis acid property.

Having identified 90 as a useful catalyst, we monitored the reaction using ${ }^{19} \mathrm{~F}-\mathrm{NMR}$ to collect some insights regarding the mechanism of the reaction. Indeed, it was important to rule out any boronic acid catalysis consecutive to a side protodeboronation reaction facilitated by the increased Lewis acidity of borinic acids. ${ }^{12}$

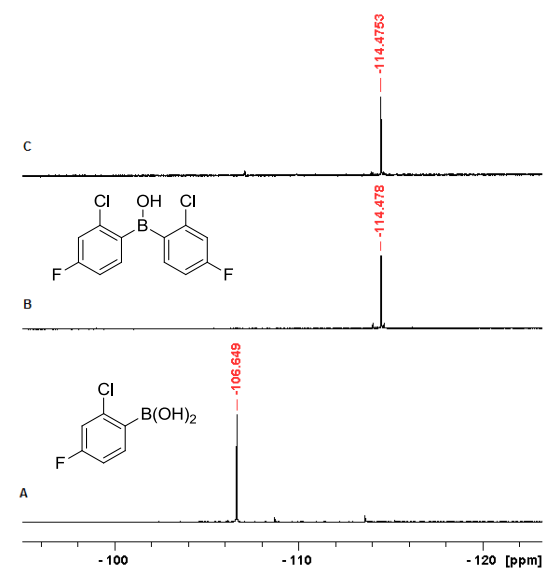

Figure 3. Monitoring the catalyst 90 behaviour using ${ }^{19} \mathrm{~F}$ probe $\left(375 \mathrm{MHz} ; \mathrm{CDCl}_{3} ; 25^{\circ} \mathrm{C}\right)$. A: isolated 2-Cl-4- $-\mathrm{C}_{6} \mathrm{H}_{4}-\mathrm{B}(\mathrm{OH})_{2}$. B: isolated 9o. C: NMR monitoring of the reaction corresponding to entry 10 , table 2 , after 6 h ( $97 \%$ conversion).

During the whole course of the reaction, a single signal at -114.5 ppm in ${ }^{19}$ F NMR (Figure 3) was observed, with no intermediates being detected. This signal matched the isolated 9o, while the corresponding boronic acid was measured at $-106.7 \mathrm{ppm}$, suggesting the stability of the catalyst 90 during the reaction.

While 9o was found to be slightly more reactive than $9 \mathrm{~h}$, the combined stability and higher availability of $9 \mathrm{~h}$ led us to select it as the optimal catalyst for the further investigations.

Before exploring dipeptide synthesis, a control reaction was carried out between phenyl acetic acid 6 and phenylalanine methyl ester $10 d$ to ascertain the absence of racemization (Scheme 1). The use of less reactive $\alpha$-amino ester $10 \mathrm{~d}$ required the use of $25 \mathrm{~mol} \%$ of catalyst $9 \mathrm{~h}$ and a switch to a different low polarity solvent and a higher temperature (fluorobenzene, $65^{\circ} \mathrm{C}$ ).

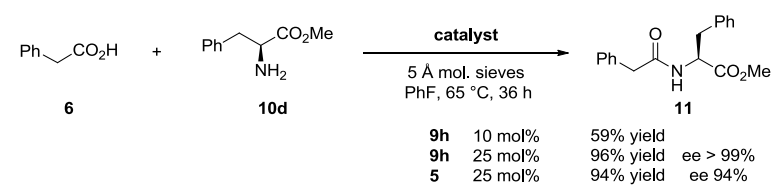

Scheme 1. Coupling between phenyl acetic acid $\mathbf{6}$ and phenylalanine methyl ester $\mathbf{1 0}$. 
Amide $\mathbf{1 1}$ was previously reported by Whiting for its propensity to provoke racemization, providing an enantiomeric excess of $68 \%$ under similar reaction conditions with catalysts $\mathbf{1 a}$ and $\mathbf{1} \mathbf{b} .{ }^{8}$ This result was previously improved using our catalyst 5 (ee: $94 \%)^{7}$ Interestingly, $\mathbf{9 h}$ afforded the desired amide $\mathbf{1 1}$ in $\mathbf{9 6 \%}$ yield with the complete retention of enantiopurity (ee $>99 \%$, Scheme 1). First attempts of coupling two protected $\alpha$-amino acids at room temperature resulted in the total absence of conversion. However using previously optimized conditions (Scheme 1), Boc-protected phenylalanine (Boc-Phe) was efficiently coupled with various methyl $\alpha$-amino esters derived from hindered Valine, Alanine, Glycine and phenylalanine in average $47-61 \%$ yields (Table 3, Entries 1-4). Similarly, Z-proline (Z-Pro) was coupled with various $\alpha$-amino esters Table 3. Scope of the reaction: peptide synthesis. ${ }^{a}$
(Table 3, Entries 5-11) in $47-73 \%$ yields. While the modification of the nature of the ester group led to marginal change when valine $\alpha$ amino ester was used (Table 3, Entries 7-8), a higher yield was obtained when an ethyl glycine ester (H-Gly-OEt) was used compared to benzyl or methyl counterparts (Table 3, Entries 9-11). Highest $80-72 \%$ yields were also obtained with the less hindered Boc-glycine (Boc-Gly-H) as the nucleophilic component of the reaction (Table 3, Entries 12-13) while Z-methionine (Z-Met) led to a non-optimized $40 \%$ yield (Table 3, Entry 14). Careful examination of the ${ }^{1} \mathrm{H}$ NMR data of all the synthesized dipeptides incorporating two chiral centres showed that a single diastereomer was obtained.

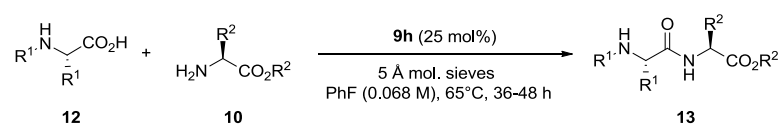

\begin{tabular}{|c|c|c|c|c|c|c|c|}
\hline Entry & $\alpha$-Amino-acid 12 & & $\alpha$-Amino-ester 10 & & Dipeptide 13 & & Yield (\%) \\
\hline 1 & Boc-Phe-H & $12 a$ & H-Val-OMe & $10 a$ & Boc-Phe-Val-OMe & $13 a$ & 51 \\
\hline 2 & Boc-Phe-H & $12 a$ & H-Ala-OMe & $10 \mathrm{~b}$ & Boc-Phe-Ala-OMe & $13 b$ & 47 \\
\hline 3 & Boc-Phe-H & $12 a$ & H-Gly-OMe & $10 c$ & Boc-Phe-Gly-OMe & $13 c$ & 55 \\
\hline 4 & Boc-Phe-H & $12 a$ & H-Phe-OMe & 10d & Boc-Phe-Phe-OMe & 13d & 61 \\
\hline 5 & Z-Pro-H & $12 b$ & H-Phe-OMe & $10 \mathrm{~d}$ & Z-Pro-Phe-OMe & $13 e$ & 60 \\
\hline 6 & Z-Pro-H & $12 b$ & H-Leu-OMe & $10 e$ & Z-Pro-Leu-OMe & $13 f$ & 60 \\
\hline 7 & Z-Pro-H & $12 b$ & H-Val-OMe & $10 a$ & Z-Pro-Val-OMe & $13 \mathrm{~g}$ & 58 \\
\hline 8 & Z-Pro-H & $12 b$ & $\mathrm{H}-\mathrm{Val}-\mathrm{OBn}$ & $10 f$ & Z-Pro-Val-OBn & $13 \mathrm{~h}$ & 59 \\
\hline 9 & Z-Pro-H & $12 b$ & H-Gly-OEt & $10 \mathrm{~g}$ & Z-Pro-Gly-OEt & $13 \mathbf{i}$ & 73 \\
\hline 10 & Z-Pro-H & $12 b$ & $\mathrm{H}-\mathrm{Gly}-\mathrm{OBn}$ & $10 \mathrm{~h}$ & Z-Pro-Gly-OBn & $13 \mathbf{j}$ & 47 \\
\hline 11 & Z-Pro-H & $12 b$ & H-Gly-OMe & $10 c$ & Z-Pro-Gly-OMe & $13 k$ & 51 \\
\hline 12 & Boc-Gly-H & $12 \mathrm{c}$ & $\mathrm{H}-\mathrm{Gly}-\mathrm{OBn}$ & $10 \mathrm{~h}$ & Boc-Gly-Gly-OBn & 131 & 80 \\
\hline 13 & Boc-Gly-H & $12 \mathrm{c}$ & H-Phe-OMe & $10 \mathrm{~d}$ & Boc-Gly-Phe-OMe & $13 m$ & 72 \\
\hline 14 & Z-Met-H & $12 d$ & H-Phe-OMe & $10 \mathrm{~d}$ & Z-Met-Phe-OMe & $13 n$ & 40 \\
\hline
\end{tabular}

${ }^{a}$ Reaction conditions: $N$-protected $\alpha$-amino acid $12(0.46 \mathrm{mmol}), \alpha$-aminoester $10(0.46 \mathrm{mmol})$ and molecular sieves ( $1 \mathrm{~g}$ of $5 \AA$ activated powder) were stirred in dry $\mathrm{PhF}(6.8 \mathrm{~mL})$ with the borinic acid catalyst $9 \mathrm{~h}(25 \mathrm{~mol} \%)$ under inert atmosphere for $32-48 \mathrm{~h}$ at $65^{\circ} \mathrm{C}$.

Based on Hall's mechanism with boronic acids, we rationalized that the $N$-protected $\alpha$-amino acid is activated in the form of the mixed boron anhydride $\mathbf{A}$ (Figure 4). This step is greatly facilitated by the increased Lewis acidity of the borinic acid $\mathbf{9 h}$. The next step involves the additions of the $\alpha$-amino ester to generate a tetravalent intermediate $\mathbf{B}$. The collapse of $\mathbf{B}$ is then assisted by water and the Lewis basicity of ortho chlorine substituents to yield eventually the desired dipeptide.
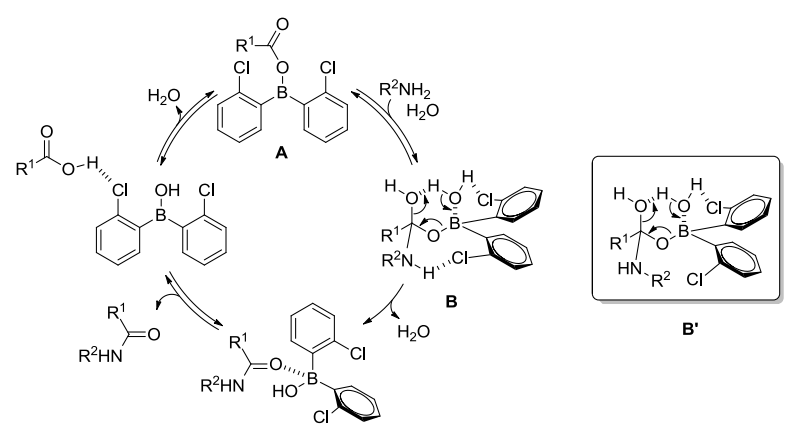

Figure 4. Proposed mechanism for the amide synthesis catalysed by the borinic acid $9 \mathrm{~h}$
To clarify if both chlorine atoms are involved, the unsymmetrical borinic acid 9p was prepared and tested (Scheme 2). With this catalyst bearing a single chlorine atom, the yield was reduced from $99 \%$ with $9 \mathrm{~h}$ (Table 2 ) to $27 \%$.

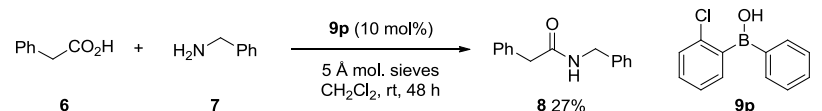

Scheme 2. Reactivity of borinic acid $9 p$ in the model reaction between phenylacetic acid 6 and benzylamine 7

Accordingly, the specific reactivity of $\mathbf{9 h}$ and $\mathbf{9 k}$ tends to indicate that both halogen atoms are probably involved in the ratedetermining step and that the intermediate $\mathbf{B}$ is formed rather than B' (Figure 4).

Indeed, mild hydrogen-halogen bondings might stabilize the transition state and favour the collapsing of B. Additionally we suggest that the formation of anhydride $\mathbf{A}$ is pre-organized by similar hydrogen-halogen bonding.

To summarize, we have uncovered the unique reactivity of borinic acids for amide and peptide syntheses. Fourteen dipeptides were 
prepared in synthetically useful yields without detectable racemization. Importantly, no stoichiometric peptide coupling reagents were used and thus minimal waste was generated with water being the sole side product of the reaction. However, there is still room for improvements; progress is necessary to match the requirements of solid phase peptide synthesis such as very high yields and short reaction times. We believe that those results will shed light on new strategies aiming at developing the catalysed peptide synthesis, which exhibits an utmost importance for the pharmaceutical industry.

We gratefully acknowledge ANR "NeoACAT" (JC 2012 program) for a fellowship to $\mathrm{TM}$ and région Basse-Normandie for financial supports.

\section{Notes and references}

1 For recent reviews about peptide synthesis, see (a) S. B. H. Kent, Chem. Soc. Rev. 2009, 38, 338. (b) A. El-Faham and F. Albericio, Chem. Rev., 2011, 111, 6557. (c) T. I. Al-Warhi, H. M. A. Al-Hazimi and A. El-Faham, J. Saudi. Chem. Soc., 2012, 16, 97. (d) S. C. Stolzew and M. Kaiser, Synthesis 2012, 44 1755. (e) V. R Pattabiraman and J. Bode, W. Nature 2011, 480, 471. (f) V. Mäde, S. Els-Heindl and A. G. Beck-Sickinge, Beilstein J. Org. Chem. 2014, 10, 1197.

2 (a) E. Valeur and M. Bradley, Chem. Soc. Rev., 2009, 38, 606 (b) C. Montalbetti and V. Falque, Tetrahedron, 2005, 61, 10827-10852. (c) K. Ishihara, Tetrahedron 2009, 65, 1085.

3 For recent reviews about catalytic amide formation, see (a) H. Lundberg, F. Tinnis, N. Selander and H. Adolfsson, Chem. Soc. Rev., 2014, 43, 2714. (b) R. M. Lanigan and T. D. Sheppard, Eur. J. Org. Chem., 2013, 7453. (c) K. Arnold, B. Davies, R. L. Giles, C. Grosjean, G. E. Smith and A. Whiting, Adv. Synth. Catal., 2006, 348, 813.

4 (a) K. Ishihara, S. Ohara and H. Yamamoto, J. Org. Chem., 1996, 61, 4196. See also (b) T. Maki, K. Ishihara and H. Yamamoto, Tetrahedron, 2007, 63, 8645. For other recent catalysed amide bond formation see: (c) D. C. Lenstra, F. P. J. T. Rutjes and J. Mecinović, Chem. Commun., 2014, 50, 5763. (d) H. Lundberg and H. Adolfsson, ACS Catal., 2015, 5, 3271. (e) Y. Terada, N. leda, K. Komura and Y. Sugi, Synthesis, 2008, 2318. (f) N. Caldwell, C. Jamieson, I. Simpson and A. J. B. Watsona, Chem. Commun., 2015, 51, 9495. (g) J. L. Vrijdag, F. Delgado, N. Alonso, W. M. De Borggraeve, N. Pe'rez-Maciasb and Jesus Alca'zar, Chem. Commun., 2014, 50, 15094. (h) M. Tamura, D. Murase and K. Komura, Synthesis 2015, 47, 769. (i) S. K. Mangawa, S. K. Bagh, K. Sharma and S. K. Awasthi, Tetrahedron. Lett. 2015, 56, 1960. (j) L. Gu, J. Lim, J. L. Cheong, S. S. Lee, Chem. Commun. 2014, 50, 7017.

5 (a) N. Gernigon, R. M. Al-Zoubi and D. G. Hall, J. Org. Chem., 2012, 77, 8386. (b) R. M. Al-Zoubi, O. Marion and D. G. Hall, Angew. Chem. Int. Ed., 2008, 47, 2876.

6 E. K. W. Tam, Rita, L. Y. Liu and A. Chen, Eur. J. Org. Chem., 2015, 1100.

7 T. Mohy El Dine, W. Erb, Y. Berhault, J. Rouden and J. Blanchet, J. Org. Chem., 2015, 80, 4532.

8 S. Liu, Y. Yang, X. Liu, F. K. Ferdousi, A. S. Batsanov and A. Whiting, Eur. J. Org. Chem., 2013, 5692.

9 The cooperative catalytic effect is still unclear but allowed to obtain Boc-Phe-Val-OMe in 55\% yield in the presence of 50 mol\% of 1 and 50 mol\% of $\mathbf{2}$ while 100 mol\% of $\mathbf{2}$ delivered $<2 \%$ yield.

10 (a) K. Ishihara, H. Kurihara and H. Yamamoto, J. Org. Chem., 1997, 62, 5664. (b) D. Lee and M. S. Taylor, J. Am. Chem. Soc., 2011, 133, 3724. (c) T. Soeta, Y. Kojima, Y. Ukaji and K.
Inomata, Tetrahedron Letters, 2011, 52, 2557. (d) M. G. Chudzinski, Y. Chi and M. S. Taylor, Aust. J. Chem., 2011, 64 1466. (e) H. Zheng, M. Lejkowski and D. G. Hall, Chem. Sci., 2011, 2, 1305. (f) E. Dimitrijević and M. S. Taylor, ACS Catal., 2013, 3, 945. (g) D. Lee, C. L. Williamson, L. Chan and M. S. Taylor, J. Am. Chem. Soc., 2012, 134, 8260. (h) Y. Mori, J. Kobayashi, K. Manabe and S. Kobayashi, Tetrahedron, 2002, 58, 8263.

11 The synthesis of $\mathbf{9 k}$ is remarkably low yielding. See supporting information for details.

12 (a) C.-Y. Lee, S.-J. Ahn and C.-H. Cheon, J. Org. Chem., 2013, 78, 12154. (b) G. Noonan and A. G. Leach, Org. Biomol. Chem., 2015, 13, 2555. 